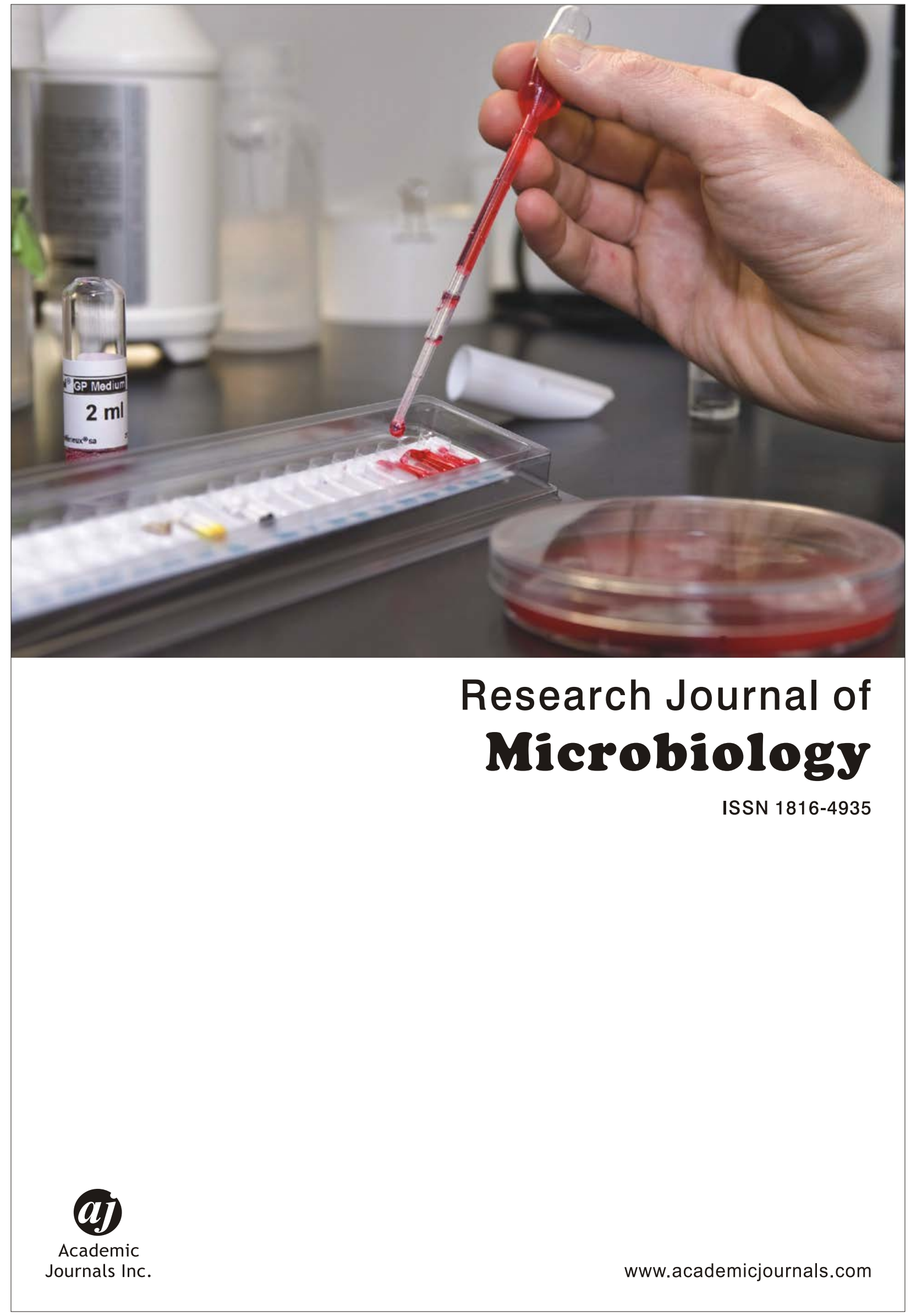


Research Journal of Microbiology 10 (10): 486-493, 2015

ISSN 1816-4935 / DOI: 10.3923/jm.2015.486.493

(C) 2015 Academic Journals Inc.

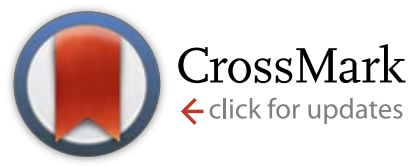

\title{
Microbiological Studies on the Production of Antimicrobial Agent by Saponin Aloe vera Linn against Streptococcus sanguinis
}

\author{
${ }^{1}$ Titiek Berniyanti and ${ }^{2}$ Erma Mahmiyah \\ ${ }^{1}$ Departement of Dental Public Health, Faculty of Dentistry, University of Airlangga, Indonesia \\ ${ }^{2}$ Departement of Dental Assistant, Poltekes Kemenkes Pontianak, Indonesia
}

Corresponding Author: Titiek Berniyanti, Department of Dental Public Health, Faculty of Dentistry, University of Airlangga, Indonesia Tel: 031.5030255, 5020256, 081330788776

\begin{abstract}
The Saponin extracts of the aerial part Aloe vera linn were examined for antibacterial activity in vitro against Streptococcus sanguinis. Streptococcus sanguinis, is a gram-positive bacteria mostly found in dental plaque. Mechanical plaque control by brushing is the most effective method for controlling plaque and also gingivitis. Saponins Aloe vera L, natural materials for the treatment and prevention of disease is a strong surface active compounds, considered as, one of the toothpaste composition and more acceptable by the body. Saponins or SLS induce to Streptococcus sanguinis bacteria and the minimal bactericidal concentrations determined by dilution method. The TEM is used, to evaluate the essential cellular function of Streptococcus sanguinis inhibited by the primary saponin-target interaction, whether they induce cell death (bactericidal drugs) or merely inhibit cell growth (bacteriostatic drugs). The variation morphological changes of bacterial cell, which is attributed to a whole cell wall with opaque cytoplasmic, cell wall separated from plasma membrane, plasma membrane rupture and event the cell wall peeled off revealed on the assays. Saponin Aloe vera L., extract was active against Streptococcus sanguinis with minimal inhibitory concentration value of $3.125 \%$. The control group SLS killed Streptococcus sanguinis with minimal inhibitory concentration value of $0.78 \%$ in all repetitions. Saponin fraction Aloe vera L. can inhibit the growth of Streptococcus sanguinis at concentration of at least $3.125 \%$.
\end{abstract}

Key words: Streptococcus sanguinis, Saponin Aloe vera, Aloe vera Linn, antimicrobial

\section{INTRODUCTION}

Natural herbal products used as prevention and treatment oral cavity disorders, currently growing rapidly. They have substances or compounds that are clinically beneficial for health and more acceptable for body, than synthetic drug. A variety of plants that can be used as, a herbal medicine, which is available in nature, one of them, was an Aloe vera. Aloe vera is the oldest medicinal plant ever known and the most applied medicinal plant worldwide. It has been planted and become potential commodity in West Profinsion of Kalimantan in Indonesia. Several species of the genus have been use under the common name of Aloe, viz. Aloe vera Linn. A. barbadensis Miller, A. ferox Miller, etc. Among these, A. vera Linn. syn. A. barbadensis Miller is the most accepted unanimously as the correct botanical source of Aloe (Rajeswari et al., 2012).

The present study carried out on the Aloe vera revealed the presence of medicinal active constituents. The phytochemical compound screened by qualitative and GC-MS method. Qualitatively analyzed saponins, tannins, flavonoids and terpenoids gave positive results in 
screening process. Saponins are glycosides occurring widely in plants, a powerful surface-active compounds, produces foam, when shaken in water and soluble in alcohol (Arunkumar and Muthuselvam, 2009). Many pharmacological activities have been reported about saponins, such as; antibiotic, antifungal, antiviral, hepatoprotective anti-inflammatory and anti-ulcer (Hostettmann and Marston, 1995). Unlike saponins in other plants that can cause irritation and hemolytic especially in the gastrointestinal tract, saponin Aloe vera can be purified, have an antiseptic and antimicrobial properties, but not to damage the surrounding tissue cells (Soetan et al., 2006).

In terms of prevention of dental disease and oral cavity, mechanical plaque control by tooth brushing is the most effective method for controlling plaque and gingivitis. But the content of detergents in the toothpaste generally is Sodium Lauryl Sulphate (SLS), which can cause the frequency of Aphthous ulcers (Bassetti and Sala, 2001). Saponin Aloe vera therefore, can be considered as, its use as, a toothpaste ingredient substitute for synthetic detergents. So far, the study of herbs as an antimicrobial against bacteria has been conducted. Streptococcus sanguinis is gram-positive bacteria are mostly found in dental plaque and first colonization of bacteria on tooth surfaces (Herlofson and Barkvoll, 1996) has been used as bacterial tested. Streptococcus sanguinis is also regarded as, opportunistic bacteria in the oral cavity, because it significantly affects the health risks and are believed to enter the bloodstream through a wound infection of the mouth and tooth extraction. They were found about $40-50 \%$ in cases of bacterial endocarditis (Yamaguchi et al., 2006). The objective of the study was to test and to evaluate the capability of saponin Aloe vera as a surfactant and their activity as an antimicrobial against Streptococcus sanguinis, as an alternative Sodium Lauryl Sulphate (SLS).

\section{MATERIALS AND METHODS}

Materials: Aloe vera Linn isolate Pontianak west Kalimantan Indonesia. Saponin fraction from Aloe vera Linn isolate Pontianak west Kalimantan Indonesia obtained by maceration and percolation in the difference concentration sort of $25,12.5,6.25,3.125,1.56,0.78$ and $0.39 \%$. Streptococcus sanguinis (bacteria) obtained from the pure stock of bacteria in the laboratory ITC Airlangga University used as bacterial tested.

Statistical analysis: The sensitivity test of saponin Aloe vera Linn against Streptococcus sanguinis, to determine the minimum concentration for killing the bacteria was conducted by dilution method as describe. The observation using Transmission Electron Microscopy to determine the employment targets of antibacterial activity of saponin fraction of Aloe vera Linn against Streptococcus sanguinis bacteria cells.

Preparation of saponin fraction Aloe vera $\mathrm{L}$ : Aloe vera $\mathrm{L}$. gel was crushed and freeze dried in a vacuum oven to heat up dry air flow $( \pm 12 \mathrm{~h})$ to get a dry powder. Aloe vera $\mathrm{L}$ dry powder then was extracted by maceration technique using, a solution of n-hexane for $10 \mathrm{~h}$ at $68-69^{\circ} \mathrm{C}$ to remove lipids and other pigments. Evaporate its residue at room temperature until the free n-hexane. Then followed by maceration with methanol at a temperature of $65.5^{\circ} \mathrm{C}( \pm 12 \mathrm{~h})$ to separate the saponin of sugar, phenolic compounds, oligosaccharides and flavonoid extract thus obtained condensed methanol. Condensed methanol extract was partitioned by adding water and n-butanol (1:1) and then stirred to obtain the fraction of water and n-butanol fraction. The fraction of n-butanol and water enter the evaporator in order to obtain good crude saponin fraction and the fraction of water. 
Saponin content in n-butanol fraction more, after the phytochemicals tested with a spectrophotometer. Saponin fraction of butanol was washed with ether, then dissolved in methanol, filtered and the filtrate was added ether excess methanol to form a white precipitate of saponin was then filtered, the residue is a saponin.

Sensitivity test saponin fraction with a difference concentration against Streptococcus sanguinis: Antimicrobials test is conducted to determine the minimum concentration of saponin were required to kill Streptococcus sanguinis by dilution method.

Samples were taken at random from the population Streptococcus sanguinis bacteria originating from the Laboratory of ITC stock Airlangga University. Germs cultured on Mueller Hinton liquid medium, which has the same turbidity with a solution of Barium Sulfate Standard (Mac Farland 0.5). Then it is diluted 100 times, performed serial dilutions of a solution of saponin/SLS. The first tube has a concentration of $25 \%$, a second tube has dilution of $1 / 2$ or $1 / 10$ of the first tube, third tubes $1 / 2$ or $1 / 10$ of a second tube, the tube until the seventh. Furthermore each tube containing $1 \mathrm{~mL}$ of saponin/SLS with each concentration of $25,12.5,6.25,3.125,1.56$, 0.78 and $0.39 \%$ added $1 \mathrm{~mL}$ of inoculum.

Last two tubes used as, positive controls and negative controls. Positive control (control of bacteria growth) tube filled with media and inoculum without drugs, whereas the negative control (sterility control) tube filled with any media without inoculum. Furthermore, each tube containing $1 \mathrm{~mL}$ of saponin/SLS with each concentration of $25,12.5,6.25,3.125,1.56,0.78$ and $0.39 \%$ added $1 \mathrm{~mL}$ of inoculum. Then, it is incubated for 18-24 h. Turbidity indicates bacterial growth. The result from re-planting of $50 \mu \mathrm{L}$ on solid media (sub culture) show that the existence of the colony showed bacterial growth.

Evaluation of bacterial cells with the transmission electron microscope: Effects of saponin fraction of Aloe vera L. was evaluated using Transmission Electron Microscope. The TEM used to determine the employment targets of antibacterial activity of saponin fraction of Aloe vera Linn against Streptococcus sanguinis (bacterial) cells. with the procedure: the cells of Streptococcus sanguinis were exposed to saponin fraction $(6.25,3.125,1.56$ for $24 \mathrm{~h}$ and $1.56 \%$ for $1 \mathrm{~h}$ ) were washed with Phosphate-Buffered Saline (PBS) pH 7.2 and fixed twice for $1 \mathrm{~h}$ at room temperature with $2.5 \%$ glutaraldehyde (grade I), $4 \%$ formaldehyde in $0.1 \mathrm{M}$ cacodylate buffer, $\mathrm{pH} 7.2$ containing $5 \mathrm{~mm}$ calcium chloride and $3.7 \%$ sucrose. Then the cells were washed with PBS and fixed for 30 min at room temperature with $1 \%$ osmium tetroxide in $0.1 \mathrm{M}$ cacodylate buffer containing $0.8 \%$ potassium ferrocyanide and $5 \mathrm{mM}$ calcium chloride. The cell then washed and dried with acetone and put in polybed 812. Excision with Reichert Ultracut S Ultramicrotome and uranyl acetate and painted with lead acetate and then observed with a Zeiss 900 transmission electron microscope at $80 \mathrm{kV}$ (Baron et al., 1994).

\section{RESULTS}

From fractionation of $4 \mathrm{~kg}$ Aloe vera chinensis, was resulted $400 \mathrm{~g}$ dry powder of Aloe vera chinensis. Then Extract heavy methanol as much as 65 gram was obtained after maseration and percolation process, From the fraksionation process of extract methanol was obtained $10 \mathrm{~g}$ of saponin deposit. 

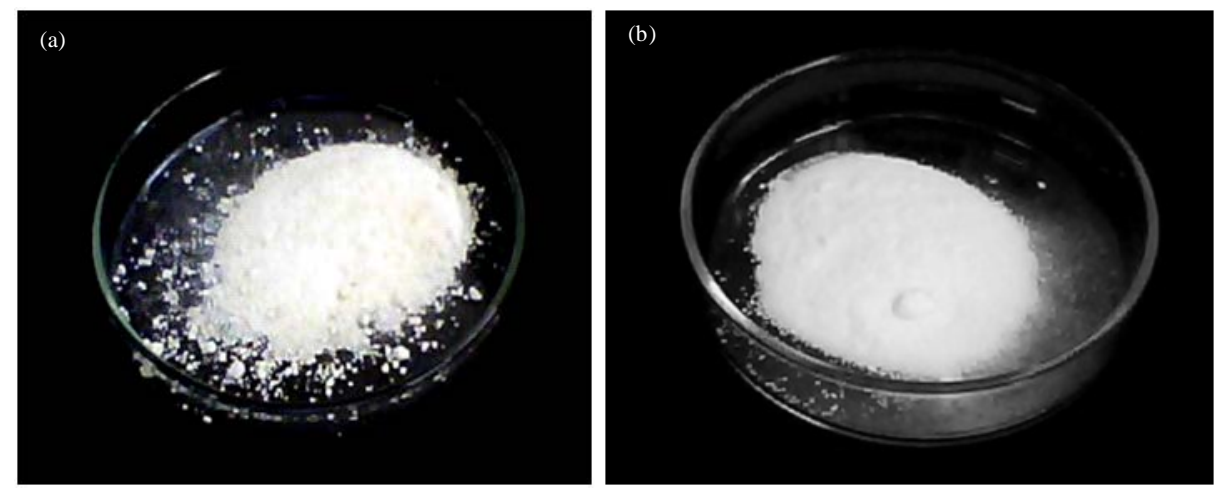

Fig. 1(a-b): (a) Powder of saponin Aloe vera and (b) Powder of sodium lauryl sulphate

Table 1: Sensitivity test saponin against Streptococcus sanguinis

\begin{tabular}{|c|c|c|c|c|c|c|c|}
\hline \multirow[b]{2}{*}{ No. replikasi } & \multicolumn{7}{|c|}{ Saponin concentration (\%) } \\
\hline & 25 & 12.5 & 6.25 & 3.125 & 1.56 & 0.78 & 0.39 \\
\hline$\overline{1}$ & -(steril) & -(steril) & -(steril) & -(steril) & $+52 \mathrm{CFU} \mathrm{mL}^{-1}$ & $\mathrm{UC}$ & $\mathrm{UC}$ \\
\hline 2 & -(steril) & -(steril) & -(steril) & -(steril) & $+74 \mathrm{CFU} \mathrm{mL}^{-1}$ & $\mathrm{UC}$ & $\mathrm{UC}$ \\
\hline 3 & -(steril) & -(steril) & -(steril) & -(steril) & $+61 \mathrm{CFU} \mathrm{mL} \mathrm{m}^{-1}$ & $\mathrm{UC}$ & UC \\
\hline 4 & -(steril) & -(steril) & -(steril) & -(steril) & $+50 \mathrm{CFU} \mathrm{mL}^{-1}$ & $\mathrm{UC}$ & UC \\
\hline
\end{tabular}

UC: Un count, CFU: Colony forming unit

Table 2: Sensitivity test sodium lauryl sulphate to Streptococcus sanguinis

\begin{tabular}{|c|c|c|c|c|c|c|c|}
\hline \multirow[b]{2}{*}{ No. perlakuan } & \multicolumn{7}{|c|}{ Saponin concentration $\left(\mathrm{mg} \mathrm{mL}^{-1}\right)$} \\
\hline & 25 & 12.5 & 6.25 & 3.125 & 1.56 & 0.78 & 0.39 \\
\hline 1 & -(steril) & -(steril) & -(steril) & -(steril) & -(steril) & -(steril) & $+12 \mathrm{CFU} \mathrm{mL^{-1 }}$ \\
\hline 2 & -(steril) & -(steril) & -(steril) & -(steril) & -(steril) & -(steril) & $+19 \mathrm{CFU} \mathrm{mL}{ }^{-1}$ \\
\hline 3 & -(steril) & -(steril) & -(steril) & -(steril) & -(steril) & -(steril) & $+12 \mathrm{CFU} \mathrm{mL} \mathrm{m}^{-1}$ \\
\hline 4 & -(steril) & -(steril) & -(steril) & -(steril) & -(steril) & -(steril) & $+11 \mathrm{CFU} \mathrm{mL}^{-1}$ \\
\hline
\end{tabular}

Resulting sample identification on the Fig. 1 was shown the active ingredient Aloe vera chinensis a yellowish powder extract (A) obtained by spectrophotometer, that are $72,44 \%$ Saponin; 0,05\% Aloin; 1,03\% Aloe Emodin dan 0,11\% Anthranol.

The antibacterial activity of Saponin Aloe vera L. extract was assayed by agar disc dilution method against Streptococcus sanguinis. Minimal inhibition concentration Determination of Saponin fraction Aloe vera L in killing the bacterium Streptococcus sanguinis can be seen in Table 1.

Table 1 showed the Minimal Inhibition Concentration of Saponin Aloe vera L. in killing Streptococcus sanguinis at the concentration 3.125. The CFU started forming at concentration of $1.56 \%$ and it was uncount on the concentration of $0.78 \%$.

Determination of Minimal Inhibition Concentration Sodium Lauryl Sulphate fraction in killing Streptococcus sanguinis can be seen in Table 2.

Table 2 showed the Minimal Inhibition Concentration Sodium Lauryl Sulphate in killing Streptococcus sanguinis was at the concentration 0.78. The CFU can be seen at concentration of $0.39 \%$ (Fig. 2-3). Evaluation of streptococcus cells after exposure to saponin Sanguinis Aloe vera L. using a transmission electron microscope. 

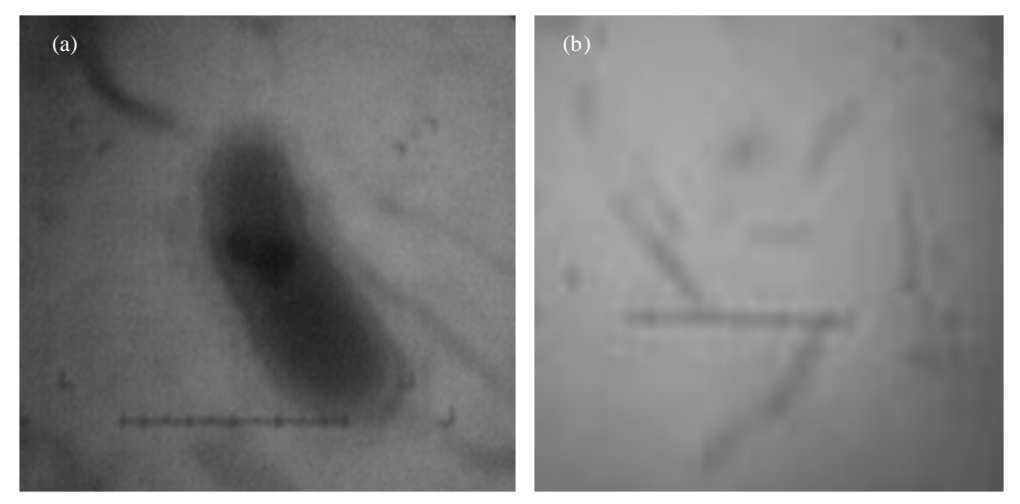

Fig. 2(a-b): Streptococcus sanguinis exposed by (a) Saponin fractions $1,56 \mathrm{mg} \mathrm{mL} \mathrm{m}^{-1}$ for $24 \mathrm{~h}$, magnification $30.000 \mathrm{x}$ revealed the rest of Streptococcus sanguinis and (b) No. Streptococcus sanguinis cells after exposed by saponin fraction $3,125 \mathrm{mg} \mathrm{mL}{ }^{-1}$, magnification $30.000 \mathrm{x}$
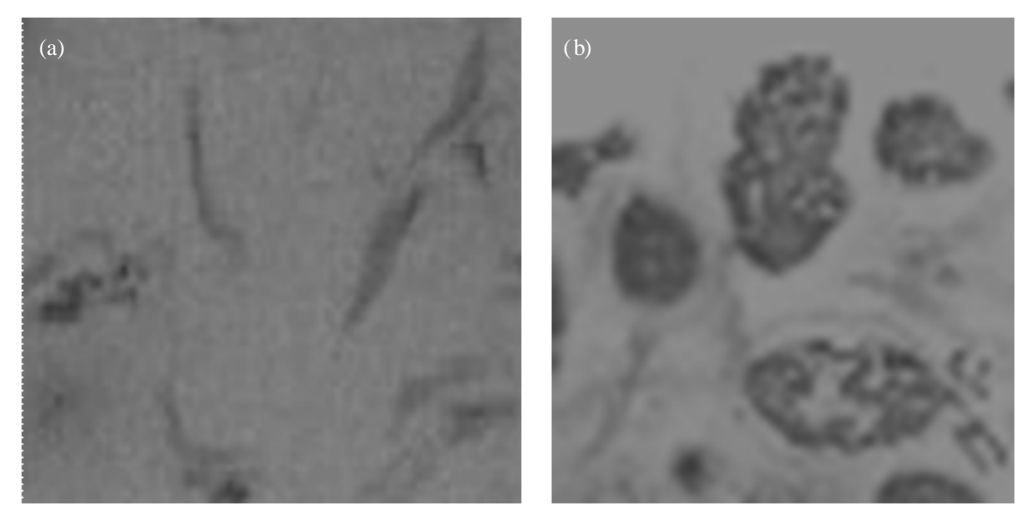

Fig. 3(a-b): Rest of Streptococcus sanguinis and no Streptococcus sanguinis cells after exposed by (a) Saponin fraction, $6.25 \mathrm{mg} \mathrm{mL}^{-1}$ magnification 25.000 and (b) Streptococcus sanguinis after exposed by saponin fraction $1.56 \mathrm{mg} \mathrm{mL}^{-1}$ for $1 \mathrm{~h}$

\section{DISCUSSION}

In this study the extraction of Aloe vera L. saponin was done by maceration and percolation techniques. This because, such techniques can be used to obtain plant extracts was thought to contain antimicrobial agents and antimicrobial activity to be tested, (Alviano et al., 2005). Methanol was chosen as, the solvent extraction study, since almost all the plant compounds that have antimicrobial activity of an aromatic compound, or dissolved in an organic compound, can be dissolved through the initial extraction using ethanol/methanol (Dey and Harborne, 1991). It is also in accordance with the methods used in plant material farmakognosi stating that alcohol is a common solvent for many compounds in plants (Cowan, 1999).

Methanol concentration was $96 \%$ for purposes other than to dissolve the compounds present in Aloe vera powder chinensis, extract also to get a bit so that the water content is more easily evaporated at low temperature to obtain the extract concentrated. Concentrated extract can be obtained by evaporating the solvent in a vacuum (in vacuo) at low temperatures so as not to damage the material that can not stand the heat (thermolabile) (Alviano et al., 2005). 
The present study carried out on the saponin fraction of Aloe vera L. revealed the presence of medicinal active constituents. The active compounds of saponin Aloe vera were qualitatively analyzed and the results are able to kill the bacteria Streptococcus sanguinis. Although, it is still a crude saponin fraction of saponin, which still contain other active ingredients, active ingredients but also has properties that could be expected to increase the positive effects of saponin. These materials, namely aloin that has a therapeutic effect as, cleaning, detoxification and antibiotics, aloe emodin has efficacy as a bactericide, while antranol is a result from anthraquinone reduction that also has antibiotic efficacy (Soetan et al., 2006).

According to Guilfoile and Alcamo (2006) inhibited growth of bacteria or bacterial death due to an antibacterial agent may be caused by, the inhibition of cell wall synthesis, inhibition of cell membrane function, inhibition of protein synthesis, or inhibition of nucleic acid synthesis (Cannell, 1998). Among the various damages that may occur in bacterial cells, which may occur in the bacterium Streptococcus sanguinis due to treatment of saponin fraction of Aloe vera L. inhibition of cell membrane function. Saponins work on the phosphate groups of the phospholipids of cell membranes and enter cells. This causes loss of membrane semi-permeability and leakage of the elements nitrogen and phosphorus. Agent enters the cell denature its protein and damage the cell membrane. While, its anionic compounds cause major disruption in the framework of the cell membrane lipoprotein (Guilfoile and Alcamo, 2006) by means polar compounds that bind to lipoproteins are nonpolar, so hydrophilic and lipophilic groups buried in the membrane lipoprotein, which resulted in the breakdown of fat occurs ion efflux and other cellular substances that the cell swelling and finally burst. Nucleic acids, nucleotides and other cellular substances that the cell swelling. This could explain the effect of inhibiting/bacteriostatic saponin fraction of Aloe vera L. against Streptococcus sanguinis cells.

Saponin also includes material which is an antiseptic, a chemical that is used on living tissue so as to prevent the occurrence of infection (Arora and Bala, 2009). Antiseptic can be used to disinfect with a sufficiently low toxicity to cells hospes that these agents can be directly applied to the skin, mucosa or wounds (Gennaro, 2000). There are several kinds of mechanism of antiseptic denaturize proteins that can damage the cell wall or cytoplasm membrane, lowering the surface tension and inhibits the synthesis of the enzyme (Arora and Bala, 2009). This study, although using minimal or smallest concentration that can kill bacteria (MBC), but to apply the concentration used in the MBC or the minimum inhibitory levels for Streptococcus sanguinis considerations used in this study, are normal flora in the human oral cavity. So, it can be expected with inhibition of bacterial growth, the body is able to kill bacteria without disturbing the balance in the oral cavity In other words, the treatment of Aloe vera L. saponin has the potential to kill the bacteria Streptococcus sanguinis totally at least has concentration of $3.125 \%$. That is, the lowest concentration to kill the bacteria Streptococcus sanguinis totally is $3.125 \%$ and for the Sodium Lauryl Sulphate (SLS) is $0.78 \%$. Thing must be considered is the concentration has been able to kill the bacteria Streptococcus sanguinis, but in general the toothpaste contained SLS concentration from 1.5-2.0\%. So we need further research on the toxicity of the material.

In the evaluation of cells Streptococcus sanguinion exposed to saponin fraction using transmission electron microscopy, it is known that exposure to saponin fraction at a concentration of $\mathrm{MBC}$, half $\mathrm{MBC}$ and twice the MBC for $24 \mathrm{~h}$ can not explain the point of capture work (mechanism) of a drug, the cell death process can not be observed because it was lysis. While the exposure to saponin fraction of $1.56 \mathrm{mg} \mathrm{mL}^{-1}$ for $1 \mathrm{~h}$ showed changes in cell shape changes that varied from less obvious that the intact cell wall with cytoplasm of an opaque, not only independent 
of the cell wall, plasma membrane rupture and the even-the cell walls is peeling. The differences may indicate differences in the damage to the end of a cell. Possible damage to normal cells but may not be captured by electron microscopy. Cells undergoing lysis is not likely to survive serious and return to its origin. Lysis of cells undergoing serious usually into fragments.

Streptococcus sanguinis is a Gram-positive bacterium with the cell wall containing many layers of acid teikoat and peptidoglycan (murein) that form thick and rigid structures that are not resistant to mechanical damage such as surface tension of cell membranes (Katzung, 2004). This can explain, the existence of parts of the cell wall is peeling on the evaluation of changes in Streptococcus sanguinis cells after exposure to saponin fraction of Aloe vera L. using TEM. In contrast to Gram-negative bacterial cell walls contain no teikoat acid and because, it contains only small amounts of peptidoglycan, the cell walls of Gram-negative bacteria are relatively more resistant to mechanical damage (Katzung, 2004). As the study conducted by Soetan et al. (2006) that saponins can inhibit the growth of Gram-positive bacteria but does not inhibit the growth of Gram-negative bacteria (Hostettmann and Marston, 1995).

Based on this research has been done can be concluded that the saponin fraction of Aloe vera L. have antibacterial activity against Streptococcus sanguinis with a minimum concentration to kill bacteria Streptococcus sanguinis at a concentration of $3.125 \%\left(3.125 \mathrm{mg} \mathrm{mL}^{-1}\right)$. While working the target saponin fraction Aloe vera L. as, bactericide against Streptococcus sanguinis cells by damaging the cell membrane.

\section{CONCLUSIONS}

The study showed that the Aloe vera L. dilutions of saponin at a concentration of $3.125 \%$ can kill Streptococcus sanguinis cells with a marked absence of germ growth after sub-culture on Mueller Hinton Agar. The control group killed Streptococcus sanguinis cells minimum levels of SLS $0.78 \%$ in all repetitions. The results of the evaluation with TEM showed visible morphological changes of bacteria, cell wall peeled and there are also appears to separate the plasma membrane of the cell wall. Saponin fraction Aloe vera L. can inhibit the growth of Streptococcus sanguinis at concentration of at least $3.125 \%$.

\section{ACKNOWLEDGMENTS}

Our heart full thanks to our Dean Faculty of Dentistry University of Airlangga, who helped us more in this research.

\section{REFERENCES}

Alviano, W.S., R.R. Mendonca-Filho, D.S. Alviano, H.R. Bizzo and T. Souto-Padron et al., 2005. Antimicrobial activity of Croton cajucara Benth linalool-rich essential oil on artificial biofilms and planktonic microorganisms. Oral Microbiol. Immunol., 20: 101-105.

Arora, D.R. and B.A. Bala, 2009. Textbook of Microbiology for Dental Students. Alkem Company (S) Pte. Ltd., Singapore, ISBN: 9789810832940, pp: 40-170.

Arunkumar, S. and M. Muthuselvam, 2009. Analysis of phytochemical constituents and antimicrobial activities of Aloe vera L. against clinical pathogens. World J. Agric. Sci., 5: $572-576$.

Baron, E.J., L.R. Peterson and S.M. Finegold, 1994. Bailey and Scott's Diagnostic Microbiology. 19th Edn., Mosby-Year Book Inc., Missouri, pp: 9, 101, 102, 170, 174. 
Bassetti, A. and S. Sala, 2001. The Great Aloe Book; History, Botani and Pharmacological Aspects of this Legendary Plant. Ist Edn., Zuccari Pty. Ltd., Via Maccani, Trento, pp: 96-97.

Cannell, R.J.P., 1998. Natural Products Isolation: Methode in Biotechnology. Humana Press Inc., Totowa, New Jersey, pp: 329-330.

Cowan, M.M., 1999. Plant products as antimicrobial agents. Clin. Microbiol. Rev., 12: 564-582.

Dey, P.M. and J.B. Harborne, 1991. Methods in Plant Biochemistry. Vol. 6, Academic Press, London, pp: 56-59.

Gennaro, A.R., 2000. Remington: The Science and Practice Pharmacy. Vol. 2., Lippincot Willians and Wilkins, USA, pp: 1205-1207, 1507.

Guilfoile, P.G. and I.E. Alcamo, 2006. Antibiotic Resistant Bacteria (Deadly Diseases and Epidemics). 1st Edn., Chelsea House, New York, USA., Pages: 128.

Herlofson, B.B. and P. Barkvoll, 1996. The effect of two toothpaste detergents on the frequency of recurrent aphthous ulcers. Acta Odontol. Scand., 54: 150-153.

Hostettmann, K. and A. Marston, 1995. Saponins (Chemistry and Pharmacology of Natural Products). 1st Edn., The Press Syndicate of the University of Cambridge, Melbourne, Australia, pp: 2, 76, 232-234, 291.

Katzung, G.B., 2004. Farmakologi Dasar dan Klinik. 1st Edn., Bagian Farmakologi Fakultas Kedokteran Universitas Airlangga, Salemba Medika, Penerjemah, Jakarta, Pages: 166.

Rajeswari, R., M. Umadevi, C.S. Rahale, R. Pushpa, S. Selvavenkadesh, K.P.S. Kumar and D. Bhowmik, 2012. Aloe vera: The miracle plant its medicinal and traditional uses in India. J. Pharmacogn. Phytochem., 1: 118-124.

Soetan, K.O., M.A. Cyekunle, O.O. Aiyelaagbe and M.A. Fafunso, 2006. Evaluation of the antimicrobial activity of saponins extract of Sorghum bicolor L. Moench. Afr. J. Biotechnol., 5: 2405-2407.

Yamaguchi, M., Y. Terao, T. Ogawa, T. Takahashi, S. Hamada and S. Kawabata, 2006. Role of Streptococcus sanguinis sortase A in bacterial colonization. Microbes Infect., 8: 2791-2796. 